\title{
Memória e amnésia sexista: repertórios de exclusão das escritoras oitocentistas
}

\section{Memory and amnesia sexist: repertoires of exclusion of eighteenth-century writers}

Anna Faedrich ${ }^{1}$

Universidade do Estado do Rio de Janeiro, Programa de Pós-Graduação Latu Sensu em Literatura Brasileira.
Rio de Janeiro, RJ, Brasil

Doutora em Letras (PUCRS). Professora Adjunta do CAp-UERJ e professora colaboradora do Programa Brasileira (UERJ). Lutor da discipin L Leratura Comparada na Graduacão em Letras a Distância (UFF/CEDERJ). Foi Pesquisadora Residente Fundação Biblioteca Nacional (2014-2015), ond realizou pesquisa sobre escritoras brasilieiras do entresseculos (1870-1930). Organizou a reediçáo do romance Exaltação (1916) de Albertina Bertha Amália, pela Gradiva Editorial em coedição com a Biblioteca Nacional.

(1) https://orcid.org/0000-0001-6616-3812

E-mail: anna.faedrich@gmail.com
RESUMO: Este texto mostra como a hostilidade para com as escritoras mulheres se relaciona ao gradual desaparecimento delas da memória e história literária brasileira. Em alguns casos de desencorajamento, por parte de uma crítica que desqualifica - de forma explícita ou velada, com ou sem razão - qualquer produção literária de autoria feminina, talentos foram interrompidos. Em outros casos, notamos o esforço por parte das escritoras para enfrentar a dominação masculina no meio literário e intelectual. 0 propósito deste texto é apresentar repertórios de exclusão das escritoras oitocentistas.

Palavras-chave: Literatura de autoria feminina; História da Literatura Brasileira; Memória; Esquecimento; Crítica Literária.

ABSTRACT: This text shows how the hostility towards women writers may be related to their gradual disappearance in the Brazilian literary memory and history. In some cases of discouragement, by a critique that disqualifies - explicitly or veiled, with or without reason - any literary production of female authorship, talents were interrupted. In other cases, we note the effort on the part of female writers to confront male domination in literary and intellectual circles. The purpose of this text is to present repertoires of exclusion of eighteenth-century writers.

Keywords: Women's writing; History of Brazilian Literature; Memory; Forgetfulness; Literature critics.

"A indiferença do mundo, que Keats, Flaubert e outros homens geniais achavam tão difícil de suportar, não era, no caso d[a mulher], indiferença, mas hostilidade." (VIRGÍNIA WOOLF, 2014, p. 78) 
hostilidade para com as escritoras mulheres pode se relacionar ao seu gradual desaparecimento da memória literária brasileira? Neste texto, argumento que sim e tento demonstrar alguns mecanismos por meio dos quais o primeiro produz implicações sobre o segundo.

Uma das lacunas na história da literatura brasileira será melhor compreendida se houver resposta ao porque o número de mulheres escritoras dignas de figurar no panteão de autores - recorrentemente celebrados, lembrados por meio revisões, resenhas, republicações, prêmios literários -, é praticamente nulo. Considerando o número de mulheres que produziram em épocas passadas, a nulidade é surpreendente. Existiram muitas mulheres ${ }^{1}$, escritoras e poetas ${ }^{2}$, que, desde meados do século XIX, publicavam, colaboravam ativamente com jornais, revistas e almanaques, e eram lidas - o que atesta que estavam inseridas no sistema literário vigente.

Em vez de, como usual, procurar demonstrar que determinada autora recebe merecimento aquém da qualidade de sua obra, adotarei estratégia analítica inversa: discutirei como a repercussão da contribuição literária feminina ensejou reações de escritores - homens - que revelam os jogos de poder e as implicações políticas com possível desdobramento sobre a fortuna das carreiras de mulheres no mundo das letras. A análise é uma contribuição para dar inteligibilidade a como uma escritora cuja obra tem repercussão, sucesso de vendas, e aptidões reconhecidas por notáveis escritores à época, a exemplo de Machado de Assis, Araripe Júnior, Monteiro Lobato, Olavo Bilac e Lima Barreto, vai gradualmente se apagando das lembranças e dos registros subsequentes.

\footnotetext{
Bastaria folhear os três volumes do monumental Escritoras Brasileiras do século XIX, organizado por Zahidé Muzart, para encontrar mais de 150 nomes de escritoras.

2 Embora já tenha utilizado abandonei o termo "poetisa" para me referir às mulheres que escrevem poemas. Mesmo que reconoca a fluidez da lín "potisa" passibilidade de ressignificar que escrevem poemas. Masta esta palavra é autoria feminina A discussão sobre qual dos ter untiza pa para literária de ainda hoje, não é A discussãonsul.
}

O que segue neste artigo são alguns exemplos de desencorajamento velados ou explícitos - por parte de uma crítica que desqualifica a produção literária de autoria feminina. 0 ponto crucial da reflexão é tornar claras as formas implícitas de menosprezo à "literatura de mulher"3 e explicitar o desalento ocultado por aparente exaltação.

As apreciações de Olavo Bilac à poesia de autoria feminina são tomadas como elogios, entretanto, a leitura acurada das entrelinhas revela a nocividade do menosprezo à manifestação literária ou intelectual feminina. É nocivo o discurso do poeta por duas implicações manifestas ou latentes: 1) mulheres inicialmente vocacionadas para a escrita a abandonaram, por não se sentirem suficientemente capazes ou por não encontrarem meios para ir além da barreira invisível - de vidro, se quiserem -, imposta por apreciações masculinas; 2) essa hostilidade branda se conecta ao exíguo e desproporcional espaço dedicado à produção das escritoras na memória da literatura brasileira.

\section{Amélia de Oliveira, poeta interrompida}

Exemplo paradigmático de uma crítica desencorajadora, dos limites que se impõem e do que se espera de uma mulher escritora no final do século XIX é a carta de Olavo Bilac à sua noiva, Amélia de Oliveira (1868-1945). A carta, datada de 1888, revela um Bilac que repreende sua noiva, poeta e irmã de Bernardo e Alberto de Oliveira ${ }^{4}$, por conta da publicação dos poemas dela

3 "Literatura de mulher" é uma expressão muito utilizada pelos homens à época para diferenciar a literatura escrita por mulheres. Acredito que esta diferenciação deliberada corrobora os três argumentos da minha pesquisa sobre o apagamento das escritoras brasileiras da memória literária: 1) a literatura é um espaço interdito às mulheres; 2) espera-se características específicas em publicações de mulheres; e 3) a crítica desqualifica suas produções literárias de forma explícita ou velada, com ou sem razão.

velada, com ou sem razão.
4 Importante líder do parnasianismo, integrante da famosa tríade Alberto de Oliveira (1857-1937), Olavo Bilac e Raimundo Correa. 
no Almanaque da Gazeta de Notícias. Autorizada a escrever, a poeta Amélia não poderia publicar sua produção lírica:

\section{Minha Amélia}

[...]

Antes de tudo, quero dizer-te que te amo, agora mais do que nunca, que não me sais um minuto do pensamento, que és a minha preocupação eterna, que vivo louco de saudade, amaldiçoando esta horrível dependência que me obriga a estar tão longe de ti. [...] Não me agradou ver um soneto teu no Almanaque da Gazeta de Notícias deste ano, não foi o fato de vir em um almanaque o soneto que me desagradou: desagradou-me a sua publicação. Previ logo que andava naquilo o dedo do Bernardo ou do Alberto. Tu, criteriosa como és, não o farias por tua própria vontade. Folguei muito, depois, vendo a minha previsão confirmada por D. Adelaide. Devo confessar que fui eu o primeiro a insistir contigo para que publicasses versos. Cheguei mesmo a dar alguns aqui, no Mercantil. Fiz mal. Arrependo-me. Hás de concordar comigo.

Há uma frase de Ramalho Ortigão, que é uma das maiores verdades que tenho lido: - "0 primeiro dever de uma mulher honesta é não ser conhecida". - Não é uma grande verdade? Reflete bem sobre isso: há em Portugal e Brasil cem ou mais mulheres que escrevem. Não há nenhuma delas de quem não se fale mal, com ou sem razão. Além disso, quem publica alguma coisa, fica sujeito à discussão, cai no domínio da crítica. E imagina que mágoa a minha, que desespero o meu, se algum dia um miserável qualquer ousasse discutir o teu nome! [...] Ainda há bem pouco tempo, aqui em S. Paulo, um padre, escrevendo sobre Julia Lopes, insultou-a publicamente. Eu nada tinha com isso. Mas tratava-se de uma senhora e da mulher de um amigo meu: tive vontade de esmurrar o padre. E sem razão. Sem razão, porque uma senhora, desde que se faz escritora, tem de se sujeitar ao juízo de todos. Não quer isto dizer que não faças versos, pelo contrário. Quero que os faças, muitos, para os teus irmãos, para as tuas amigas, e principalmente para mim, - mas nunca para o público, porque o público envenena e mancha tudo o que lhe cai sob os olhos [...] Teu noivo, Olavo Bilac. (Grifos meus. ELTON, 1954, p. 48-54).

A justificativa para impedir a publicação dos poemas da noiva é uma estratégia perspicaz: converter a interdição da literatura às mulheres em preocupação do noivo com a reputação da amada. Em um primeiro momento, Bilac se apoia no discurso moralista do escritor português Ramalho Ortigão (1836-1915) - “O primeiro dever de uma mulher honesta é não ser conhecida" - como estratégia de convencimento, solicitando que Amélia reflita bem sobre tal "verdade". Uma "verdade" que não é dele, Bilac, mas de outro. Mesmo que a preocupação em questão seja sincera “[...] imagina que mágoa a minha, que desespero o meu, se algum dia um miserável qualquer ousasse discutir o teu nome!" -, o discurso atesta certa "fragilidade feminina", que impediria qualquer poeta mulher ou escritora de suportar uma crítica. Os homens a suportariam, as mulheres não. Por trás deste argumento, revela-se a hostilidade para com as mulheres que "se atrevem" a escrever e publicar. O vaticínio sobre a sorte de mulheres é enfático: “[...] há em Portugal e Brasil cem ou mais mulheres que escrevem. Não há nenhuma delas de quem não se fale mal, com ou sem razão".

Este passo-a-passo dos argumentos contidos na carta revela exemplo paradigmático da violência simbólica, doce - porque desconhecida enquanto tal - (BOURDIEU, 2001, p. 251) das políticas de exclusão vivenciadas por nossas escritoras.

Estratégia igualmente eficaz é lançar mão do exemplo de outra escritora da época, conhecida e amiga, Júlia Lopes de Almeida. Mostrar o que está acontecendo com aquelas que ousaram se assumir escritoras é uma forma de amedrontar Amélia. O modo como o caso é narrado é bastante meticuloso. Primeiro, ele se mostra irritado ao ver que a escritora, esposa de seu amigo ${ }^{5}$, está sendo insultada publicamente. Depois, se diz sem razão, culpabilizando a mulher por se fazer escritora: "E sem razão. Sem razão, porque uma senhora, desde que se faz escritora, tem de se sujeitar ao juízo de todos". Com isso, Bilac consegue mostrar a Amélia o que acontecerá com

$\overline{5}$ O poeta português Filinto de Almeida (1857-1945). 
ela, caso continue publicando seus poemas, e transfere a culpa por qualquer insulto ou difamação para a mulher. Trata-se de um beco sem saída, pois as escritoras estão predestinadas aos maus comentários, independentemente do valor e da análise de suas obras ${ }^{6}$. Dessa forma, percebe-se que as intempéries da trajetória literária feminina não foram poucas.

Depois de tanto investimento retórico, Bilac atinge o seu propósito. Desencorajada pelo noivo e por um sistema literário excludente, Amélia abandona a poesia, como nos mostra Elmo Elton em $O$ noivado de Bilac:

Amélia de Oliveira, depois deste pedido de Bilac, deixou de publicar seus versos, tendo mesmo perdido o estímulo para a literatura. Não fez nome literário, embora para isso não lhe faltasse oportunidade. Era talentosa e contava, sobretudo, para a divulgação de seus trabalhos na imprensa, com o invejável prestígio de seu irmão Alberto de Oliveira, com que residiu por longos anos. Conhecia de perto todos os grandes escritores da época, que lhe admiravam a inteligência e cultura (ELTON, 1954, p. 51-52, nota de rodapé).

Segundo Maria de Lourdes Eleutério (2005), Presciliana Duarte de Almeida, a "promotora das letras femininas", insistiu - sem sucesso - para que Amélia continuasse escrevendo e publicando. Entretanto, a poeta interrompida continuou fiel ao pedido de seu ex-noivo:

[Presciliana Duarte de Almeida] usou em seu livro Vetiver o pseudônimo "Amélia de Oliveira", e esclareceu em uma nota que a autora, a quem pertencia verdadeiramente o nome, infelizmente não publicava seus versos. Presciliana pede a Amélia que faça poemas e os divulgue, mas não é atendida. A "noiva-viúva" resignou-se ao pedido do príncipe dos poetas.

Teve a vida longa, e, mesmo idosa, ia todas as semanas levar flores no túmulo do amado (ELEUTÉRIO, 2005, p. 39).

\footnotetext{
${ }^{6}$ Vale notar que ainda não superamos esse perfil de crítica. Em alguns casos, ela perdura e persiste em atribuir a sistemática exclusão das mulheres à [dita] falta de qualidade das obras, sem, contudo, apresentar análise literária satisfatória ou o mínimo de conhecimento da literatura escrita por mulheres. Não é raro também o hábito de exigir das escritoras oitocentistas valor literário pautado nos critérios de análise atuais. Além de a acrônica, essa crítica - perversa e preconceituosa - demo nos

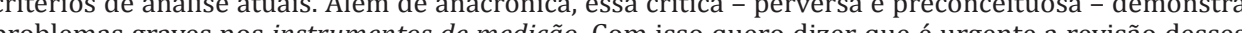

\section{Maria Firmina dos Reis, precursora ${ }^{7}$ na ousadia de publicar}

A carta de Olavo Bilac à Amélia de Oliveira é um caso exemplar de uma crítica hostil e dos limites que se esperam de uma mulher escritora no final do século XIX. Caso curioso é o prólogo do romance Úrsula (1859), assinado por “Uma Maranhense”. Nele, Maria Firmina dos Reis (1825-1917) demonstra a ousadia e o risco que é para uma mulher escritora publicar sua obra literária. Consciente da provável recepção adversa, que será indiferente à obra ou escrachada, a autora insiste na sua publicação - "e ainda assim o dou à lume" -, por isso é uma atitude transgressora. 0 tom humilde do discurso parece vir para aplacar a intelligentsia. A escritora, que utilizou um pseudônimo no livro, se vê instada a justificar o "atrevimento" de publicar seu romance. Vale ressaltar também a denúncia sutil da condição desfavorável da mulher à época:

Mesquinho e humilde livro é este que vos apresento, leitor. Sei que passará entre o indiferentismo glacial de uns e o riso mofador de outros, e ainda assim o dou à lume.

Não é a vaidade de adquirir nome que me cega, nem o amor próprio de autor. Sei que pouco vale este romance, porque escrito por uma mulher e mulher brasileira, de educação acanhada e sem o trato e a conversação dos homens ilustrados, que aconselham, que discutem e que corrigem, com uma instrução misérrima, apenas conhecendo a língua de seus pais, e pouco lida, o seu cabedal intelectual é quase nulo (REIS, 1859, p. 5).

Para Eleutério (2005), mesmo que a mulher conquiste as condições intelectuais e sociais para escrever, tais como o acesso à educação, leituras

7 Entre as precursoras, encontra-se a escritora catarinense Ana Luísa de Azevedo Castro (1823-1869) que publicou em folhetim o romance D. Narcisa de Villar, em 1858, sob o pseudônimo Indygena do Ypiranga. 
e aprendizado de línguas estrangeiras, convivência com escritores e intelectuais, participação em saraus e na imprensa, ainda encontrará "impedimentos de ordem vária: internalizará a inferioridade que a sociedade patriarcal forjou para ela, não se achando apta a competir com seus irmãos, ou se submetendo completamente aos desígnios da família que a tolhe ou lhe faz o primeiro reconhecimento" (ELEUTÉRIO, 2005, p. 25).

$\mathrm{O}$ tom humilde do prólogo aqui analisado pode ser uma estratégia astuciosa de entrada no meio masculino das letras, pois ao desqualificar o romance apresentado não coloca em risco a produção literária dos demais escritores. Ainda assim, se era esta a estratégia, não logrou êxito: o livro pouco circulou e não permaneceu em nossos registros literários. Entretanto, o ato de se desqualificar também pode ser interpretado como uma forma internalizada de sua inferioridade por ser mulher. A autora de Úrsula define a sua obra como "tímida e acanhada", "sem dotes da natureza, nem enfeites e louçanias da arte", ou seja, uma forma de se posicionar como incapaz de fazer alguma coisa à altura do que os homens fazem. "Uma maranhense" fala em defesa de sua obra, pedindo que a deixem circular, de modo a ser lida. E revela a necessidade de incentivo e de aval para continuar escrevendo e publicando:

Deixai pois que a minha Úrsula, tímida e acanhada, sem dotes da natureza, nem enfeites e louçanias da arte, caminhe entre vós. Não a desprezeis, ante ampare-a nos seus incertos e titubeantes passos para assim dar alento à autora de seus dias, que talvez que com essa proteção cultive mais o seu engenho, e venha a produzir coisa melhor, ou quando menos, sirva esse bom acolhimento de incentivo para outras, que com imaginação mais brilhante, com educação mais acurada, com instrução mais vasta e liberal, tenham mais timidez do que nós (REIS, 1859, p. 6).

\section{Auta de Souza, pequenina joia}

Amélia de Oliveira não foi exemplo singular no que diz respeito à hostilidade da crítica feita por homens à literatura de autoria feminina.
Olavo Bilac e seus contemporâneos desestimularam uma série de escritoras com comentários que diminuíam sua capacidade intelectual e o valor literário de suas obras. Trato aqui de uma crítica dissimulada, que sugere tom elogioso, entretanto, traz de forma subentendida os ataques mais perversos às escritoras mulheres, só perceptíveis por meio de uma leitura crítica apurada. Tal reprimenda velada é tão nociva e violenta quanto à explícita. E o mais grave: muitas vezes não a detectamos.

No prefácio ao único livro de poemas publicado por Auta de Souza (1876-1901) - Horto, de 1900 -, Bilac ${ }^{8}$ inicia afirmando que "Não há nas estrofes do Horto o labor pertinaz de um artista, transformando as suas ideias, as suas torturas, as suas esperanças, os seus desenganos em pequeninas joias" (2009, p. 29). Os comentários do poeta parnasiano em relação à produção poética de Auta de Souza não são inocentes. Nas entrelinhas daquilo que aparenta ser elogioso - "[...] um livro como este, de uma tão simples e ingênua sinceridade, é a coisa que surpreende e encanta" (2009, p. 29); “[...] neste formoso volume, que vem revelar uma poetisa de raro merecimento" (2009, p. 31); "um desses raros livros que se leem e releem com um encanto crescente" (2009, p. 31) -, desvelam-se julgamentos perniciosos, que demonstram uma visão simplista e redutora dos poemas escritos por uma mulher.

Em outro momento, Bilac afirma "Aqui a alma vibra em liberdade, sem a preocupação dos enfeites da Forma, livre da complicada teia de artifício" (2009, p. 29). 0 tom elogioso à espontaneidade da poeta potiguar mascara a mensagem implícita de que seus poemas não têm o labor de um verdadeiro artista, são frutos da inspiração, e de que a poeta não é capaz de

8 Olavo Bilac escreveu o prefácio a pedido de seu amigo Henrique Castriciano de Souza, irmão de Auta de Souza e figura prestigiada no Rio Crande do Norte. Henrique foi poeta, estudioso da cultura, educador drama furgo, assumiu dramaturgo, assumiu cargos de assessoria no Governo do Estado. Alem de Henrique, Auta teve outros

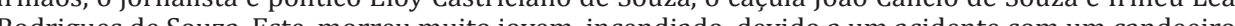


complexidades formais pertinentes ao gênero lírico. A hostilidade encoberta de tal censura, que coloca em xeque a capacidade intelectual de uma mulher, se esconde até mesmo de críticos argutos. Considerando que Bilac é poeta parnasiano, ávido cultor das formas poéticas, fica nítido o cinismo de seu enaltecimento. Ademais, Bilac reitera a ingenuidade de Auta, faz questão de pontuar que se trata de uma "alma de mulher", além de reforçar o protótipo da mulher meiga e sensível: "Ingenuamente, comovida e meiga, essa alma de mulher vai traduzindo em versos os mundos de sensações, agora ardentes, agora tristes, que o espetáculo da vida vai lhe sugerindo" (BILAC, 2009, p. 29).

Gilberto Araújo, em Literatura Brasileira: pontos de fuga, dedica um capítulo à Auta de Sousa, apresentando uma análise minuciosa de seus poemas. Araújo demonstra certo estranhamento em relação aos elogios de Bilac à espontaneidade da poeta, mas, mesmo assim, considera favorável a recepção crítica da obra:

A primeira edição de Horto, rapidamente esgotada e hoje raridade bibliográfica, recebeu favorável recepção crítica, tendo sido prefaciada por Olavo Bilac. Curiosamente, o príncipe dos parnasianos elogiou a espontaneidade de Auta de Souza, despreocupada com a Forma e rendida à inspiração (ARAÚJO, 2014, p. 186).

Zahidé Muzart afirma que Auta de Sousa "não integrou o bloco das esquecidas", por conta da vasta fortuna crítica de Horto: "temos os nomes respeitados de Otto Maria Carpeaux, Alfredo Bosi, Massaud Moisés e Luís Câmara Cascudo. [...] Encontram-se verbetes sobre a poetisa nos principais dicionários de literatura, nas histórias da literatura e seus poemas estão nas antologias" (MUZART, 1991, p. 149). Como a própria estudiosa conclui, "isso não quer dizer que hoje seja lida, estudada, conhecida" (MUZART, 1991, 149-150). Retomo, aqui, a minha questão de análise: o que aconteceu para que essas escritoras, reconhecidas à época, fossem excluídas da memória e história literárias, ao ponto de hoje não termos sequer notícias delas? Acredito que um dos mecanismos de exclusão esteja relacionado às entrelinhas dos comentários críticos acerca das obras. Constatar que grandes nomes da elite intelectual liam, comentavam e recebiam "bem" essas obras, não é suficiente. Passo fundamental é a análise do teor do que é dito sobre a produção literária de autoria feminina. Voltemos ao caso dos prefácios de Horto.

Como se não bastasse o prefácio de Bilac à primeira edição, as edições seguintes também têm prefácios escritos por homens que diminuem o valor de Horto ou tentam pintar uma Auta de Souza santificada, tal como ocorreu na segunda edição de 1910, que recebeu prefácio do irmão Henrique Castriciano:

Ela não conheceu os obstáculos que encheram de tormento a existência de Marcelline Desborde Valmore. Desde muito cedo, porém, sentiu todo o horror da morte. [...] Horto é pois a história de uma grande dor. Formou-o a autora recordando, sentindo, penando. [...] Tudo isso ocorreu muitíssimo para agravar a maravilhosa sensibilidade de seu temperamento de mulher [...] Não teve cultura literária vasta. [...] A tormenta se desfizera ao pé do túmulo; e do naufrágio em que se abismou esta singular existência, resta o Horto, livro de uma santa (Grifos meus. CASTRICIANO, 2009, p. 33-35).

Ademais, Castriciano desvaloriza a cultura literária da irmã, o que pode ser contestado pelo fato de a poeta esbanjar domínio das técnicas da lírica9 ${ }^{9}$ sendo, inclusive, considerada autodidata por conta dos poucos anos de estudo formal que teve.

A terceira edição, de 1936, contou com prefácio de Alceu Amoroso Lima (Tristão de Athayde). Este texto é interessante para pensarmos as condições de escrita da mulher, pois dialoga com a carta de Bilac à Amélia. Tristão de

9 Recomendo a leitura do ensaio já mencionado "Auta ou o nome também engana", de Gilberto Araújo (2014). A análise cuidadosa de Araújo sobre os poemas de Horto revela um valor estético da poesia de Auta que não foi devidamente reconhecido por sua crítica. 
Athayde afirma que Auta fez versos para si e para os que a cercavam, não sonhou com a glória literária. Será que a poeta não sonhou com a glória literária ou ela não teve o direito de sonhar? As intempéries da trajetória literária feminina acabam relegando sua produção ao espaço doméstico e íntimo. Bilac foi categórico e convincente ao proibir sua noiva de publicar os poemas que ela escrevia. Aqui, neste prefácio, fica explícita a noção de uma "corrente das letras femininas", que seria, é claro, muito diferente - leia-se inferior - das letras masculinas:

Auta de Souza não pertence nem a uma escola nem a um momento literário. Filiada, por natureza, à corrente das letras femininas em nosso país, nela se destaca, no dizer de Jackson de Figueiredo - 'como a mais alta expressão do nosso misticismo, pelo menos, do sentimento cristão, puramente cristão, na poesia brasileira'. [...] Fez versos para si e para aqueles que mais de perto a cercavam. Nunca sonhou com a glória literária. Nem mesmo com esse eco que só depois de morta veio encontrar no coração dos simples, onde toda um aparte dos seus poemas encontrou a mais terna repercussão (LIMA, 2009, p. 37-38)

\section{Albertina Bertha, mais um capítulo da crítica desencorajadora}

Em 1926, Monteiro Lobato lamentou a mudança de perfil das escritoras no início do século XX:

Outrora, no Brasil de anquinhas, ser poetisa era suspirar. [...] Hoje tudo mudou. Se há suspiros, é em casa das doceiras: clara de ovo batida com açúcar e assada no forno aos pingões. Suspiro poético, arrancado ao imo da alma à força de contrações do diafragma e sibilo de nariz, isso morreu, saiu de moda, acabou. E é pena (Grifo meu. LOBATO, 2008, p. 193).

O lamento de Lobato deixa revelar a condição feminina à época, o casamento como o negócio supremo da vida das mulheres e o fato de não poderem sequer escolher seus maridos: "Se não tinha graça num marmanjão de cabeleira que morria hético aos 20 anos, tinha-a demais nas representações do sexo hoje ex-frágil, cujos corações não eram consultados nem para o negócio supremo das suas vidinhas: casar" (LOBATO, 2008, p. 193).

Considero importante a análise crítica do lamento de Lobato. Aparentemente, o comentário é favorável às escritoras, uma vez que Lobato afirma que há mais graça "nas representações do sexo hoje ex-frágil" do que "num marmanjão de cabeleira". Entretanto, quando Lobato afirma que a poeta "emparelhou-se com o poeta moderno" e, por isso, se elevou a nível superior, fica nítida a concepção de uma literatura de autoria feminina inferior, feita por "poetisas"10, em contraposição à literatura escrita pelas "demais criaturas de elegância mental, distinção e sobriedade de maneiras":

A poetisa de hoje emparelhou-se com o poeta moderno. [...] Compuseramse. Alçapremaram-se a nível superior. Emparelharam-se às demais criaturas finas de elegância mental, distinção e sobriedade de maneiras (Grifo meu. LOBATO, 2008, p. 193).

Comentários como esses, acabam naturalizando a produção poética de mulheres como "a arte de suspirar", bem como a sua desvalorização. São mecanismos subliminares de dominação masculina, que perpetuam distinção valorativa entre a escrita literária e a produção intelectual de homens e mulheres. Estes mecanismos acabam se transfigurando e manifestando de outras formas, como nos processos de seleção dos nomes a constar nas histórias da literatura.

${ }^{10}$ Assim como a expressão "literatura de mulher" era utilizada para diferenciar a literatura escrita por mulheres, o termo "poetisa" também foi utilizado com este fim. Hoje, o uso do adjetivo "feminina" enquanto qualificador de literatura tem sido motivo de muitas discussões e controvérsias. "Poetisa" acabou se tornando um termo pejorativo, tanto quanto "literatura de mulher", utilizado sobretudo pelos homens do século XIX para menosprezar a poesia feita pelas mulheres. Se analisarmos as críticas à época, comprovamos que foi isso mesmo o que aconteceu. Neste texto, lanço mão de vários exemplos esclarecedores. 
A escritora carioca Albertina Bertha de Lafayette Stockler é um caso para um artigo inteiro, pois ela é uma voz dissonante na belle époque brasileira, por demonstrar visão crítica à condição feminina à época e inconformidade com a sociedade patriarcal; levantar bandeira à favor da educação das mulheres; escrever romances com ousadia temática, tratando de temastabu como o adultério e o desejo feminino; por ser uma erudita que escreve ensaios e ministra conferências sobre filosofia, em especial sobre Nietzsche; ter a leitura de seus romances proibida dentro de sua própria família; ser considerada uma corrompedora pelas vozes conservadoras à época; ter sucesso de vendas de seu primeiro romance, Exaltação, e por tê-lo reeditado seis vezes em vida etc.

Em troca de correspondências com Lima Barreto, Albertina Bertha enfrenta aquilo que todas as escritoras à época enfrentaram: uma crítica desencorajadora. Passemos à análise de um trecho da carta do autor de Policarpo, escrita em 31 de dezembro de 1916:

O seu livro é bem um poema em prosa, e um poema de mulher, de senhora, pouco conhecedora da vida total, dos altos e baixos dela, da variedade de suas cores e das suas injustiças. Vivendo à parte, em um mundo muito restrito, a senhora, muito naturalmente, não podia conhecer senão uma espécie de dor, a dor de amar; e, dessa mesma, a senhora faz dela uma Exaltação. [...] Com tão belos dotes de estilo, com tanto vigor de imagens, com língua tão quente e tão firme, com tanta beleza verbal, eu espero ver desdobrar-se a vitoriosa autora de Exaltação em uma George Sand ou em uma George Eliot, nesta principalmente (Grifo meu. BARRET0,1956, p. 284-285).

Vale notar que Exaltação é um romance de introspecção, em que o leitor tem acesso à mente narrada da protagonista e à expressão da subjetividade. Talvez por isso, Barreto afirme ser um "poema em prosa". Entretanto, ao rotulá-lo como "poema de mulher, de senhora", já apresenta marcas de preconceito de gênero, pois desmerece o conhecimento de vida da autora - "pouco conhecedora da vida total" - sobretudo pelo fato de Albertina Bertha pertencer a uma família abastada, o que justificaria a acusação de que ela não conhece as variedades das cores e das injustiças da vida. Outra expectativa muito comum em relação às características da literatura de autoria feminina é que as mulheres escrevam sobre o amor e que esta seja uma ficção doméstica. Na carta de Lima Barreto, tais especificidades ficam explícitas, quando ele escreve que Bertha vive "à parte, em um mundo muito restrito" e por isso não poderia "conhecer senão uma espécie de dor, a dor de amar".

Apesar da crítica, Albertina Bertha mantém-se forte, diferentemente de outras escritoras que abriram mão do ofício por conta da opressão. Segundo relatos dos familiares de Albertina, ela era uma mulher inabalável e convencida de sua inteligência, que contava com todo o estímulo do pai - o intelectual e político Conselheiro Lafayette - e do marido. Quanto à carta de Barreto, Albertina responde de forma irônica - afirmando-se conhecedora não apenas de uma dor, mas de sete dores - e um tanto debochada ao dizer "Mas que fazer se sou assim, totalmente eivada desse mal divino e ingênito":

Doutor Lima Barreto,

$[\ldots]$

Agradeço-lhe a sinceridade com que se refere ao meu livro e ao meu modo de ser. Diz-me que, vivendo à parte, num mundo especial, hei de naturalmente simplificar a vida e só conhecer uma espécie de dor - a dor de amar.

Talvez; sei apenas que há dias em que a minha alma traz as sete dores: dores cruciantes, estéreis, lívidas, sem lágrimas, sem consolo, sanguíneas. [...]

Ah, bem sei que transformo a realidade, que a doiro apesar de minha visão física, que a não descrevo com minúcias, com detalhes de verdade, que a dignifico, que a elevo, que minto... Mas que fazer se sou assim, totalmente eivada desse mal divino e ingênito, dessa morbideza inexplicável mas incisiva e penetrante, veneno das minhas vísceras e do meu espírito (BARRETO, 1956, p. 285). 
Em carta a Monteiro Lobato, Lima Barreto revela insatisfação com a pouca venda de seus livros. Neste excerto, o escritor comenta o sucesso de vendas de Albertina Bertha e Gilka Machado, demonstrando rivalidade ao se comparar com elas. A forma como Lima Barreto justifica o sucesso das duas escritoras cariocas é por meio do menosprezo dos livros delas e dos próprios leitores do Rio de Janeiro, pois associa indiretamente o sucesso de ambas à tendência erótica e à falta de critérios do leitor carioca. Aqui, fica claro que o que ele, Lima Barreto, escreve tem qualidade, e por ter qualidade não vende tanto, já que os leitores não são inteligentes:

0 meu Policarpo do qual tirei 2.000, há dois anos, está longe de esgotarse, apesar de tê-lo vendido (a edição) quase pelo preço da impressão. A Dona Albertina Berta foi mais feliz e a D. Gilka Machado, com seus livros de versos, a $5 \$ 000$ a plaquete, ainda mais. Isto dá a medida da inteligência do leitor do Rio. [...] Além disso, uma outra coisa influi poderosamente no sucesso do livro: a tendência erótica, com uma falta total de pensamento próprio sobre as coisas e homens do meio. 0 leitor carioca não quer julgamento... (Grifos meus. BARRETO, 1956b, p. 57).

O campo literário é um espaço de disputa, e escritoras podem colocar em risco a literatura produzida por homens. Uma forma de afastá-las desse ofício é desencorajando-as para tal. E uma forma de alijá-las da memória literária é desqualificando a sua escrita. 0 argumento se torna plausível, pois se a literatura é ruim, é "de mulher", "de senhora”, é menor, não tem porquê ser registrada nas histórias literárias ${ }^{11}$. Por um lado, podemos admitir que esses homens não consideravam mesmo a literatura produzida por mulheres de valor; por outro lado, podemos considerar o medo do poder feminino e

${ }^{11}$ A hostilidade para com a literatura de autoria feminina pode justificar o descaso em relação ao espólio das escritoras brasileiras. Se a família não acredita no valor desses escritos, acaba por não preservar seu espólio, o que nos impossibilita o acesso aos manuscritos, registros diversos, cartas recebidas e não enviadas, e obras não publicadas. Vale lembrar do caso de Castro Alves, que, após sua morte, contou co a da ñ Adelaide de Castro Alves para organizar seus poemas para publica ão, Segundo Eleutério, Adelaide “continuou a cultuar o irmão a ser memória viva da qual se nut çaço. de mais uma concorrência em um espaço literário de disputa intelectual e mercadológica. Nesse sentido, a análise crítica de Rosa Monteiro mostra-nos que o receio ante o poder feminino vem desde os primeiros mitos de nossa cultura e está presente nas narrativas sobre a criação do mundo (Eva, Pandora - culpadas pela mortalidade, pela enfermidade e pelo tempo - e Lilith): "por um lado se esforçam por definir o papel subsidiário das mulheres, mas, ao mesmo tempo, outorgam-nos uma capacidade de fazer dano muito superior ao nosso lugar de segundogênitas" (MONTEIRO, 2008, p. 10-11).

O diálogo entre a protagonista do Exaltação, Ladice, e seu marido, sutilmente alude à concepção masculina em relação aos perigos da educação da mulher:

- Não quero destruir crenças - disse ela - apenas abolir costumes arraigados na ignorância e acobertados pela moral. Oh! Se todos descessem até a luz suprema, até a essência das coisas... Como o mundo seria outro! E os seus olhares se perdiam nos tons fuscos da tarde que desaparecia.

- A moral em boca feminina deve merecer acatamento, respeito; é sagrada como a religião.

- A moral - Ladice sorriu, é a veste fornecida por cada século para colorir as convenções humanas então na moda... Ela varia como o tempo, como qualquer mulher histérica.

- Mas, Ladice, de onde tiraste estes conceitos? Falas como uma revolucionária.

E suas sobrancelhas se contraíram.

- Fui buscá-los na minha inteligência, na observação, no sofrimento, nos atos dos próprios homens...

- São os efeitos da educação viril que recebeste... É um mal terrível, esse modernismo, esta mania tola, de instruir-se a mulher, como se fora um rapaz.

- Desejavas então que eu fosse ignorante, e que apenas soubesse ler e escrever?

- Garanto-te que serias muito mais feliz... Perderias esse romantismo que te enferma - replicou ele, sem segunda tensão (Grifo meu. BERTHA, 2015, p. 173-174). 
A instrução permite-nos olhar criticamente para o mundo que nos cerca. A protagonista Ladice quer "abolir os costumes arraigados na ignorância e acobertados pela moral". Por seu perfil questionador, Ladice é acusada de revolucionária. 0 marido considera que a "educação viril" recebida pela mulher é que a "desvirtuou" - "É um mal terrível, esse modernismo, esta mania tola, de instruir-se a mulher, como se fora um rapaz".

\section{Narcisa Amália, gênio do mal}

A poeta fluminense Narcisa Amália, considerada uma das primeiras feministas no Brasil, enxergava com lucidez a condição da mulher no século XIX. Em 31 de dezembro de 1886, em carta publicada em A Família, Narcisa afirma: "Suponho ter sido eu, no Brasil, quem primeiro ergueu a voz clamante contra o estado de ignorância e de abatimento em que jazíamos" (AMÁLIA, in: OSCAR, 1994, p. 63).

No artigo "A mulher do século XIX", Narcisa relacionou a inteligência feminina a uma espécie de "armas para o mal". O olhar crítico da poeta lhe dava pleno discernimento da "profunda separação intelectual e moral" entre homens e mulheres:

A educação da mulher! Mas tem a mulher por acaso necessidade de ser educada? Para quê? Cautela! A mulher representa o gênio do mal sob uma forma mais ou menos graciosa e cultivar a sua inteligência seria fornecer-lhe novas armas para o mal. Procuremos antes torná-la inofensiva por meio da ignorância. Guerra, pois, à inteligência feminil!

Eis a palavra do século passado. [...]

Nada há que justifique essa tenaz perseguição da mulher; e entretanto foi perpetuada de século a século!

A mulher no século dezenove acha-se, portanto, emancipada, isto é, entra na posse de si mesma, conquista o direito divino de sua alma, em uma palavra, transfigura-se. 0 que lhe falta ainda para ser feliz? - À que está emancipada, pouco; mas à que está por emancipar-se, tudo. E neste caso está a mulher brasileira. Entre nós a instrução, mesmo a mais elementar, tem até aqui constituído monopólio do homem. Ora, à medida que o homem sobe, a mulher desce, naturalmente, e essa diferença cria entre ambos uma profunda separação intelectual e moral que arrasta consigo todas as desordens do lar (Grifo meu. AMÁLIA, in: RAMALHO, 1999, p. 129)

A angústia de Narcisa Amália em relação à iniquidade de gênero se revela por meio de suas cartas. Ao amigo Alfredo Sodré ${ }^{12}$, lamenta a dificuldade de uma mulher se revelar artista e inteligente face ao meio desfavorável em que vive. Como bem observa Norma Telles, "tanto na vida quanto na arte, a mulher no século passado aprendia a ser tola, a se adequar a um retrato do qual não era a autora" (TELLES, 2013, p. 413). A observação ecoa a de Narcisa, para quem a mulher se habitua "ao balbucio de insignificantes frases convencionais". Ademais, a metáfora sufocante de uma mulher enclausurada que se debate em vão e vê sua inteligência ser arruinada é extremamente ilustrativa do tormento que vive uma mulher consciente de sua condição:

[...] como há de a mulher revelar-se artista se os preconceitos sociais exigem que o seu coração cedo perca a probidade, habituando-se ao balbucio de insignificantes frases convencionais? Vitimada pela opressão, galé do círculo murado em que inutilmente se debate, a mulher inteligente acompanha com mágoa a extinção gradativa de sua fecundidade cerebral, seguindo com olhos rasos de pranto a inspiração que ala-se para sempre, movendo em largo vôo sereno as asas flamejantes, menos feliz que a pomba da tradição bíblica, sem ter encontrado um ramo de loureiro onde por instante repousasse... (AMÁLIA, in: REIS, 1949, p. 103).

Em carta de 1873 a José Palmela ${ }^{13}$, a poeta lamenta por as mulheres não poderem cursar Academias, demostrando certa inferioridade ao se comparar com Palmela. O tom é similar ao de Maria Firmina dos Reis no prólogo de Úrsula: "Não tem esses ligeiros trabalhos o mérito de vossas

${ }^{12}$ Carta a Alfredo Sodré publicada n'O Guaratuja, 19 abr. 1898. In: REIS, 1949, p. 103.

${ }^{13}$ Carta a José Palmela publicada n'A República, 11 maio 1873. 
produções, mas encerram como elas as primícias de uma alma de moça que não pôde cursar Academias, ainda entre nós cerradas às santas aspirações da inteligência feminina" (AMÁLIA, in: OSCAR, 1999, p. 64).

Machado de Assis, em sua crônica elogiosa a respeito de Nebulosas (1872), comenta que

Há, sem dúvida, alguma página menos aperfeiçoada, algum verso menos harmonioso, alguma imagem menos própria; mas, além de que esses senões melhor os conhecerá e me dará a autora com o tempo (e um talento verdadeiro não deixa de os conhecer e emendar), é antes de admirar que o seu livro não saísse menos puro, dadas as condições de uma estreia (MACHADO DE ASSIS, 1872).

Infelizmente, Narcisa Amália não publicou mais e, com isso, não pudemos acompanhar esse "talento verdadeiro" após a "condição de estreia”. As intempéries da sua trajetória intelectual e pessoal não foram poucas. Sofreu preconceito por ter sido casada duas vezes e ter se separado dos dois maridos, por ser inteligente e bonita, par de adjetivos interdito, por ser escritora, jornalista profissional, feminista e independente. Teve a autoria de seus poemas colocada em xeque. Mesmo tendo notável recepção de seu livro, recebendo o consagrado prêmio "lira de ouro", entre outras homenagens, sendo admirada pelo Imperador D. Pedro II, pelo escritor Machado de Assis e outros poetas importantes, Narcisa Amália é mais um, entre tantos, exemplos de mulheres vítimas de um apagamento injusto.

\section{Teresa Margarida da Silva e Orta, autora do primeiro romance brasileiro}

É praticamente consensual que o primeiro romance brasileiro é $A$ moreninha (1844), de Joaquim Manuel de Macedo. Embora $O$ filho do pescador (1843), de Teixeira e Sousa, seja considerado o introdutor do romantismo no Brasil, por ser cronologicamente anterior ao de Macedo, não teria a mesma qualidade literária daquele ${ }^{14}$.

Em se tratando do início do Romantismo em nosso país, a querela sempre foi em torno da paternidade do romance brasileiro. Não há, hoje, conhecimento sobre a produção literária de mulheres à época e sequer questionamos se houve tal produção. Agora, imagine não haver uma paternidade, mas uma maternidade pioneira do romance romântico brasileiro?

Como vimos ao longo deste texto, sempre foi uma ousadia para a mulher se afirmar enquanto escritora e publicar seus livros. Qual não seria a ousadia agora afirmarmos que a primeira romancista brasileira é mulher, e que seu romance foi publicado um século antes, 92 anos antes daquele que hoje é canonizado como o precursor?

Quem retifica o erro da história literária do Brasil, solicitando a inclusão de Teresa Margarida Silva e Orta (1711-1793) como a precursora do romance brasileiro, é Rui Bloem:

0 primeiro romance brasileiro não foi, entretanto, nenhum dos indicados por esses historiadores. Nem cabe a Pereira da Silva, Teixeira e Souza, ou Macedo o título de primeiro romancista brasileiro. Nem tão pouco a época apontada como a do aparecimento do gênero no Brasil oscila entre 1839 e 1844.

0 primeiro romance brasileiro surgiu um século antes, em 1752. [...] Este livro chamava-se, na primeira edição, Máximas de Virtude e Formosura mas tornou-se mais conhecido pelo nome com que apareceu nas edições posteriores: Aventuras de Diófanes (BLOEM, 1993, p. 221-222).

${ }^{14}$ Em Formação da Literatura Brasileira, Antonio Candido afirma que a qualidade literária de $O$ filho do pescador é "de terceira plana", entretanto, considera a sua "importância histórica, menos por lhe caber até nova ordem a prioridade na cronologia do nosso romance (não da nossa ficção), do que porer até nova ordem a prioridade na cronologia do nosso romance (não da nossa ficção), do que por representar no Brasil, inaciçamente, o aspecto que se convencionou chamar folhetinesco do "muito inferior a próprio Macedo" (2006, p. 102) notando que a de Teixeira e Sousa "subliterária" "o aspecto mecânico que nela assume a intriga" (2006, p. 103), isto é, a essência do folhetim. 
Interessa-me, aqui, analisar a recepção e o discurso sobre o livro de Teresa Margarida, para compreender os mecanismos de exclusão da literatura de autoria feminina dos nossos registros, histórias e memória.

Teresa Margarida, autora de Máximas da virtude e formosura, com que Diófanes, Clymenea e Hemirena, Príncipes de Tebas, venceram os mais apertados lances da desgraça (1752) ${ }^{15}$, é mencionada na introdução de Aurélio Buarque de Holanda ao $O$ filho do pescador. Holanda faz menção aos estudos de Ernesto Ennes e de Rui Bloem sobre a escritora e não questiona o possível pioneirismo feminino, mas a nacionalidade da autora:

Indiscutível, pois, que se deve a uma brasileira um romance lançado noventa e um anos antes de 0 filho do pescador. 0 que não me parece líquido é que essa mulher nascida no Brasil seja uma escritora brasileira, e que portanto seja brasileiro seu romance (FERREIRA, 1977, p. 6).

O crítico literário sustenta que Teresa Margarida nasceu em São Paulo, mas se mudou ainda criança para Portugal, sendo, portanto, de fato uma escritora portuguesa. Presumindo ser este um argumento válido, ele é suficiente para justificar nossa ignorância em relação a esta escritora? Se o posto de precursor do romance brasileiro é relegado a Teixeira e Sousa por conta da inferioridade estética de sua obra, e mesmo assim é perpetuado na memória literária por sua importância histórica (cronologia e caráter folhetinesco), por que Máximas da virtude e formosura, escrito 92 anos antes, em português, por uma escritora nascida em São Paulo, não recebe sequer uma ponta de relevância histórica? Nem mesmo o direito à dúvida e à polêmica - quais devem ser os critérios de nacionalidade? - as histórias literárias mais conhecidas registram.

${ }^{15}$ Publicado em 1752, sob o pseudônimo Dorothea Engrassia Tavareda Dalmira, anagrama de Dona Theresa Margarida da Silva e Orta.
É, no mínimo, arbitrária a conclusão a que chega Aurélio Buarque, ao contrariar Silvio Romero e Rui Bloem em relação à nacionalidade brasileira atribuída a todos que nasceram no Brasil: “[...] em última análise, se assim é, Teresa Margarida será uma autora luso-brasileira” (HOLANDA, 1977, p. 8). Para Holanda, Margarida é uma escritora portuguesa porque, devido ao fato de viver toda sua vida em Portugal, "seu romance nada reflete do nosso meio, que ela, praticamente, não conhecia" (HOLANDA, 1977, p. 8). Aqui entramos em outra discussão que é o projeto nacional brasileiro do século XIX, que enseja e premia o discurso forjado e ufanista para "erigir a nação". A função dos escritores românticos, para colaborar na construção - inventada e desenhada - da nação, é tratar explicitamente da cor local, do retrato do Brasil e de assuntos nacionalistas em seus romances. Teresa Margarida teria sido alijada por fugir à regra.

O mais intrigante é que Holanda reconhece maior qualidade literária em Teresa Margarida ao compará-la com Teixeira de Sousa. A qualidade literária da obra, agora, figura em plano irrelevante, uma vez que a literatura se tornou lugar de debate sobre a identidade do país e, desde então, a crítica tem privilegiado obras literárias com esse caráter social, que discute a especificidade nacional, revelando o vício de discurso nacional que se instaurou no passado:

Fraquíssimo, não é ele [O filho dos pescador], no entanto, como o de Teresa Margarida - de muito melhor qualidade -, uma tentativa solta, ocasional, infecunda. [...] 0 mestiço de Cabo Frio é que dá começo à história do nosso romance - do romance brasileiro, situado no Brasil, feito por filho do País, de espírito formado na terra, e a ela radicalmente ligado (HOLANDA, 1977, p. 8-9).

Reescrever a história da literatura brasileira com novos enquadramentos faria emergir uma nova história. Uma história em que, por exemplo, o discurso de afirmação da nação, ou a 'vida indiana', no caso do romantismo, 
sejam apenas um dos aspectos de um mosaico, mais diverso e complexo da produção literária, em cada período. Em 1873, o visionário Machado de Assis já se preocupava com as limitações do discurso fundador vigorante. Em resposta ao pedido de "notícias sobre a atual literatura brasileira", feito por Sousândrade ${ }^{16}$, Machado de Assis questiona a necessidade do discurso nacionalista, da idealização da paisagem local e do índio como herói brasileiro para criar uma literatura mais independente: "Devo acrescentar que neste ponto manifesta-se às vezes uma opinião, que tenho por errônea: é a que só reconhece espírito nacional nas obras que tratam de assunto local, doutrina que, a ser exata limitaria muito os cabedais da nossa literatura" (MACHADO DE ASSIS, 1992, p. 803).

Se nossos critérios de avaliação da literatura brasileira mudaram, se compreendemos que "não está na vida indiana todo o patrimônio da literatura brasileira, mas apenas um legado, tão brasileiro como universal, não se limitam os nossos escritores a essa só fonte de inspiração" (MACHADO DE ASSIS, 1992, p. 803), já podemos assumir a maternidade do romance brasileiro com a paulista Teresa Margarida de Silva e Orta. Pelo menos, até nova ordem.

\section{Considerações finais sobre a "amnésia sexista"17}

As ementas das disciplinas de literatura brasileira, sobretudo no período do Romantismo, reproduzem o cânone de escritores homens. Há uma imperceptível exclusão, naturalizada, pois a ausência se justifica como um dado de origem, da falta de direitos à época, como o direito das mulheres

${ }^{16}$ Joaquim de Sousa Andrade (1833-1902), mais conhecido como Sousândrade, poeta e escritor brasileiro, pediu para Machado de Assis um texto sobre a atual literatura brasileira, pois ele se encontrava na Europa há muito tempo. Machado de Assis escreve sob encomenda, e o artigo é publicado na revista nova-iorquina Novo Mundo, em março de 1873

${ }^{17}$ Expressão utilizada por Rosa Monteiro, em Histórias de mulheres, 2008, p. 18. à educação, que culminava na inexistência de mulheres produtoras de literatura que merecem figurar na memória.

Este texto apresentou, por meio de exemplos, alguns mecanismos de exclusão das mulheres do meio intelectual e literário brasileiro, em particular em séculos passados. Há uma agenda de pesquisa por ser feita, que mapeie e analise outros mecanismos, novos exemplos, em toda sua complexidade, sutileza e implicações. Se a história da literatura reproduz seleções arbitrárias, é também um instrumento para reconstruir narrativas em novas perspectivas. Tal reconstrução, necessária, é um trabalho literário e político.

\section{Referências}

AMÁLIA, Narcisa. "Uma carta”, a Alfredo Sodré. O Garatuja, Resende, 19 abr. 1889. In: REIS, Antônio Simões dos. Narcisa Amália. Rio de Janeiro: Organizações Simões, 1949. p. 103.

AMÁLIA, Narcisa. Carta a José Palmela. A República, 11 maio 1873. In: OSCAR, João. Narcisa Amália: vida e poesia. Campos: Lar Cristão, 1994. p. 64.

AMÁLIA, Narcisa. Carta. A Família, 31 dez. 1886. In: OSCAR, João. Narcisa Amália: vida e poesia. Campos: Lar Cristão, 1994. p. 63.

AMÁLIA, Narcisa. "A mulher no século XIX". In: RAMALHO, Christina. Um espelho para Narcisa: reflexos de uma voz romântica. Rio de Janeiro: Elo, 1999. p. 128-132.

AMÁLIA, Narcisa. Nebulosas. Apresentação e posfácio de Anna Faedrich. 2ed. Rio de Janeiro: Gradiva Editorial; Fundação Biblioteca Nacional, 2017.

ARAÚJO, Gilberto. "Auta ou o nome também engana". In: ARAÚJO, Gilberto. Literatura Brasileira: pontos de fuga. Rio de Janeiro: Verve, 2014. p. 185-214.

ASSIS, Machado de. Notícia da atual literatura brasileira. Instinto de Nacionalidade. Obra completa. Vol. III. Rio de Janeiro: Nova Aguilar, 1992.

BARRETO, Lima. Correspondência. Tomo I. São Paulo: Brasiliense, 1956.

BARRETO, Lima. Correspondência. Tomo II. São Paulo: Brasiliense, 1956b. 
BERTHA, Albertina. Exaltação. Organizadora Anna Faedrich. Porto Alegre: Gradiva, Rio de Janeiro: Fundação Biblioteca Nacional, 2015.

BILAC, Olavo. Prefácio da $1^{\underline{a}}$ edição. In: SOUZA, Auta de. Horto, outros poemas $e$ ressonâncias: obras reunidas. Organização Alvamar Medeiros, Ana Laudelina Ferreira Gomes e Angelita Araújo. Natal: EDUFRN - Editora da UFRN, 2009, p. 29-31.

BLOEM, Rui. "O primeiro romance brasileiro: retificação de um erro da história literária do Brasil". In: ORTA, Teresa Margarida da Silva e. Obra reunida. Introdução, pesquisa bibliográfica e notas de Ceila Montez. Rio de Janeiro: Graphia Editorial, 1993. p. 219-233.

BOSI, Alfredo. História concisa da Literatura Brasileira. 43. ed. São Paulo: Cultrix, 2006.

BOURDIEU, Pierre. Meditações pascalinas. Tradução Sergio Miceli. Rio de Janeiro: Bertrand Brasil, 2001.

CANDIDO, Antonio. Formação da Literatura Brasileira: momentos decisivos 1750-1880. 13 a ed. Rio de Janeiro: Ouro sobre Azul, 2012

CASTRICIANO, Henrique. Prefácio da 2a edição. In: SOUZA, Auta de. Horto, outros poemas e ressonâncias: obras reunidas. Organização Alvamar Medeiros, Ana Laudelina Ferreira Gomes e Angelita Araújo. Natal: EDUFRN - Editora da UFRN, 2009, p. 33-35.

ELTON, Elmo. $O$ noivado de Bilac. Com a correspondência inédita do poeta à sua noiva D. Amélia de Oliveira. Rio de Janeiro: Organização Simões, 1954.

HOLANDA, Aurélio Buarque de. Introdução. In: TEIXEIRA E SOUSA, Antônio Gonçalves. O filho do pescador. São Paulo: Melhoramentos, 1977. p. 5-26.

LIMA, Alceu Amoroso. Prefácio da 3 a edição. In: SOUZA, Auta de. Horto, outros poemas e ressonâncias: obras reunidas. Organização Alvamar Medeiros, Ana Laudelina Ferreira Gomes e Angelita Araújo. Natal: EDUFRN - Editora da UFRN, 2009. p. 37-38.

LOBATO, Monteiro. “Em pleno sonho, 1926”. In: LOBATO, Monteiro. Na antevéspera. São Paulo: Globo, 2008.

MACHADO DE ASSIS, Joaquim Maria. “Nebulosas”. Semana Illustrada, n. 629, 29 dez. de 1872.

MONTEIRO, Rosa. Histórias de mulheres. Tradução de Joana Angélica d'Avila Melo. Rio de Janeiro: Agir, 2008.

ORTA, Teresa Margarida da Silva e. Obra reunida. Introdução, pesquisa bibliográfica e notas de Ceila Montez. Rio de Janeiro: Graphia Editorial, 1993.
PAIXÃO, Sylvia Perlingeiro. "Narcisa Amália". In: MUZART, Zahidé Lupinacci (Org.). Escritoras brasileiras do século XIX. 2. ed. rev. Florianópolis: Editora Mulheres; Santa Cruz do Sul: EDUNISC, 2000, p. 534-552.

REIS, Antônio Simões dos. Narcisa Amália. Rio de Janeiro: Organizações Simões, 1949. REIS, Maria Firmina dos. Úrsula. São Luís: Tipografia do Progresso, 1859.

SOUZA, Auta de. Horto, outros poemas e ressonâncias: obras reunidas. Organização Alvamar Medeiros, Ana Laudelina Ferreira Gomes e Angelita Araújo. Natal: EDUFRN Editora da UFRN, 2009.

TELLES, Norma. "Escritoras, escritas, escrituras". In: DEL PRIORE, Mary. História das mulheres no Brasil (Org.). 10. ed. $2^{\text {a }}$ reimpressão. São Paulo: Contexto, 2013. p. 401-442. WOOLF, Virginia. Um teto todo seu. Tradução de Bia Nunes de Sousa, Glauco Mattoso. São Paulo: Tordesilhas, 2014.

Recebido em 02/02/2018

Aceito em 05/05/2018. 